\title{
ANÁLISE CURRICULAR DE DOIS CURSOS DE GRADUAÇÃO EM MATEMÁTICA: BRASIL E CHILE
}

\author{
ANÁLISIS CURRICULARES EN DOS CURSOS DE LICENCIATURA EN \\ MATEMÁTICA: BRASIL Y CHILE
}

\section{CURRICULAR ANALYSIS OF TWO UNDERGRADUATE COURSES IN MATHEMATICS: BRAZIL AND CHILE}

\author{
Danillo Diaz Levicoy ${ }^{1}$ \\ Edvonete Souza de Alencar ${ }^{2}$
}

RESUMO: O artigo apresenta um estudo documental comparativo, no qual analisou-se os planos de curso e os documentos curriculares de duas graduações em Matemática. A investigação foi realizada nos documentos do referido curso da Universidade Católica de Maule e da universidade Federal da Grande Dourados. Nosso objetivo foi identificar similaridades e diferenças entre os currículos formativos e promover a reflexão sobre a formação dos futuros professores. Para subsidiar nossa investigação além dos documentos analisados, realizamos uma busca de artigos científicos que se propuseram a investigar essa temática. Em um estudo preliminar e ainda não finalizado identificamos semelhanças em algumas disciplinas ofertadas, mas diferenças significativas a organização das disciplinas.

PALAVRAS-CHAVE: Currículo. Formação inicial de professores. Matemática.

RESUMEN: El artículo presenta un estudio documental comparativo, en el cual se analizaron los planes de curso y los documentos curriculares en dos graduaciones en Matemáticas. La investigación se realizó en los documentos del referido curso de la Universidad Católica de Maule y de la Universidad Federal de la Grande Dourados. Nuestro objetivo fue identificar semejanzas y diferencias entre los currículos formativos y promover la reflexión sobre la formación de los futuros maestros. Para subsidiar nuestra investigación más allá de los documentos analizados, realizamos una búsqueda de artículos científicos que se propusieron investigar esta temática. En un estudio preliminar y aún no finalizado identificamos semejanzas en algunas disciplinas ofrecidas, pero diferencias significativas en la organización de las disciplinas.

PALABRAS CLAVE: Currículo. Formación inicial de profesores. Matemáticas.

\footnotetext{
1 Universidad Catolica del Maule (UCM), Maule - Chile. Professor. Doctorado en Ciencias de la Educación pela Universidad de Granada (2018). Máster en Didáctica de la Matemática pela Universidad de Granada (2014). ORCID: https://orcid.org/0000-0001-8371-7899. E-mail: dddiaz01@ gmail.com ${ }^{2}$ Universidade Federal de Grande Dourados (UFGD), Dourados - MS - Brasil. Professora Adjunta do Magistério Superior. Doutora em Educação Matemática pela PUC-SP (2016). Mestre em Educação Matemática pela Universidade Bandeirante de São Paulo (2012). ORCID: https://orcid.org/0000-00025813-8702. E-mail: edvonete.s.alencar@hotmail.com
} 
ABSTRACT: The article presents a comparative documentary study, in which the course plans and the curricular documents of two graduations in Mathematics were analyzed. The research was carried out in the documents of said course of the Catholic University of Maule and the Federal University of Grande Dourados. Our goal was to identify similarities and differences between the formative curriculum and to promote reflection on the formation of future teachers. In order to subsidize our investigation beyond the documents analyzed, we conducted a search for scientific articles that set out to investigate this issue. In a preliminary study and still not finalized we identified similarities in some offered disciplines, but significant differences the organization of the disciplines.

KEYWORDS: Curriculum. Initial teacher training. Mathematics.

\section{Introduction}

In recent years, the area of Mathematics Education has focused on investigating the curricular aspects between them that guide the formation of the Mathematics teacher. This interest has been investigated by the countries of Latin America, given the difficulties they see in the results of external evaluations, in student learning and in the challenges to teaching.

Thus, in this article we present a comparative documentary investigation of the pedagogical projects of the Mathematics course in two Brazilian institutions (Federal University of Grande Dourados) and Chilean University (Universidade Católica do Maule).

For the accomplishment of this investigation it was necessary to make a brief bibliographical review on the Curriculum theme for the teaching of Mathematics, specifically for the segment of Higher Education and the initial teacher education and training, that we will use as theoretical reference for the analyzes and reflections of our investigation.

\section{The Curriculum in Mathematics Teaching: Theoretical Framework}

In this section we look for authors who could refer us about the curriculum and the initial teacher education and training for the teaching of Mathematics, although it is a subject still little discussed we find Pires (2015) that brings reflections on the Brazilian curriculum and how they see consolidating themselves and Rico (2019), which provides studies on the curriculum in general and how it can be used in teacher education. 
Pires (2015) was one of the forerunners in research on the curriculum of mathematics in Brazil and left a great body of research on the subject. With this, we look for one of the articles coming from a presentation at the III National Forum on Mathematics curricula. In this presentation she presents a survey of Brazilian theses and dissertations on the subject, as well as exposes the existing public policies.

The author focuses on the following questions: (a) What do we know about investigations that focus on mathematics curricula? (b) How are the public policies that relate to curricular issues in Brazil conducted? (c) What do curricula represent in everyday school practices? (d) What is the role of forums and research groups in discussions and projects on Mathematics Curricula? (PIRES, 2015, p.8)

Pires (2015) reports on the data of Palanch (2015) that carried out a survey of state-of-the-art investigations, and was conducted at the Thesis Bank of the Coordination of Superior Level Staff Improvement (CAPES). A total of 366 surveys were identified from post-graduation programs in Education, from 1987 to 2012.

Of this amount, 116 investigations were selected and it was possible to observe the thematic and design that the investigations have been conducting in the last 10 years on mathematics curriculum. These were analyzed using 3 categories: 1) Trajectories and curricular fundamentals, in which the aims of mathematics were observed in the curricula of basic education, methodological questions, history of mathematics curricula; 2) Levels of curriculum achievement, observed curricula prescribed and the implementation of curricular innovations, curricula presented, in action and evaluated; 3) Curricula in practice that study the Disciplinary, Interdisciplinary or Transdisciplinary Curricular organization, Content Blocks that make up the Mathematics Curriculum and its diversity.

Research reveals the distance between the prescribed curriculum and the curriculum present in the classrooms, identifying the teacher's difficulty in knowing why mathematics is taught and how it is taught. These aspects point to the need to analyze the curricula of the initial formation of Mathematics teachers, a topic evidenced in the discussion forums and congresses.

Pires (2015) still refers to other researches he has done comparing different curricula from Latin American countries, in which he noted that Brazil's curricular documents are consulted by the education and university departments, while in other Latin American countries there are no consultations with educational bodies. In 
addition, the curricular documents in Brazil are not mandatory, already in other Latin American countries is a mandatory document.

With regard to public policies, the author mentions the need for the construction of curricular documents in Brazil that are effectively used for teaching quality mathematics.

Thus, it mentions that Brazil has specific legislation that guides teaching such as the Guidelines for Early Childhood Education, Elementary and Secondary Education, and later came the Law of Guidelines and Bases and National Curricular Parameters. Regarding the specificities for the curriculum in higher education to LDB 9394/96 brings some guidelines of general specifications. The author also mentions that in the year 2015 there was a government proposal in the

The author also mentions that in 2015 there was a proposal from the government to create the National Curricular Common Base - BNCC, which is currently enacted but did not meet the specificities listed by the researchers in the area, to promote a reflection-oriented teaching, in research and in dialogue to obtain quality education.

Currently, the base guides the teaching of Basic Education and as a consequence guides the specificities with which teachers must be trained in view of the contents that will be addressed in the segment of education that will act.

Regarding teacher training, the author affirms the need for formative studies that contemplate the activities:

it is necessary that the curriculum be a subject of study of teachers both in their initial formation and in continuing education, which is not always a common practice today. Discussion of these official documents, analysis of curricular materials, planning of sequences of activities based on learning objectives, should be essential tasks in teacher training (PIRES, 2015, p. 13)

Thus, curricular studies must according to Pires (2015) be in the formative actions with the teachers.

Rich in previous studies of the year 1998 already considered that the teacher to work with Mathematics needed to have specific knowledge for teaching. This knowledge permeates curricular knowledge and thus Rico (2019) presents in a parallel conference in the event of the Inter-American Committee on Mathematics Education some specificities of the Mathematics curriculum. 
Initially presents the general notions of the Mathematics Education curriculum

Table 1 - The general notions of the curriculum

\begin{tabular}{|l|l|l|}
\hline Denotes (Shows) & planning & practice \\
\hline Program & Proposal for action & achievement \\
\hline Consist statement & Principles & Practical Translations \\
\hline Counterpoint & Prescription & Occurrence \\
\hline Concrete & Guiding & Principles \\
\hline
\end{tabular}

Source: Rico (2019) our translation.

This table shows in a summary way the characteristics that the mathematics curriculum has: the program, which consists of the curriculum, its concrete actions and counterpoints. In addition, it proposes the planning for the proposal of action in the classroom, the principles inherent in the actions and their prescription. All these actions are put into practice through the realization, translation of occurrence and orientation.

Rico (2019) also mentions about the dimensions of the curriculum, which are a) cognitive, b) cultural / conceptual, c) ethical / formative and d) social. These dimensions, according to the author, are considered to be substantive and independent, and are characterized by specific disciplinary studies. Therefore, the dimensions are interrelated and have systemic character, and therefore support the studies and analysis of the curriculum. They have as a characteristic the selection of didactic contents as their study themes. They can also potentiate the organization of the structures of these didactic contents, identifying and establishing categories and variables for their analysis, are structured according to different levels of curricular reflection.

Thus, the author presents some central concepts for each dimension

Table 2 - Study objects and modalities analysis according to the dimensions

\begin{tabular}{|l|lr|l|c|}
\hline \multicolumn{5}{|c|}{ Curricular Dimension } \\
\hline dimension & $\begin{array}{l}\text { Cultural } \\
\text { conceptual } \\
\text { dimension }\end{array}$ & $\begin{array}{l}\text { Ethical / formative } \\
\text { dimension }\end{array}$ & Social dimension \\
\hline \multicolumn{5}{|c|}{ Study objects didactic content } \\
\hline Intentionality in & $\begin{array}{l}\text { Meanings of } \\
\text { school mathematics }\end{array}$ & $\begin{array}{l}\text { Planning athematical } \\
\text { mamplementation of }\end{array}$ & $\begin{array}{c}\text { Critery and } \\
\text { decision making }\end{array}$ \\
\hline
\end{tabular}




\begin{tabular}{|l|l|l|l|}
\hline \multicolumn{1}{|c|}{ learning } & content in school & $\begin{array}{l}\text { tasks for teaching } \\
\text { mathematics }\end{array}$ & $\begin{array}{c}\text { based on learning } \\
\text { achievement }\end{array}$ \\
\hline \multicolumn{3}{|c|}{ Modality of didactic analysis } \\
\hline $\begin{array}{l}\text { Cognitive analysis } \\
\text { of content }\end{array}$ & $\begin{array}{l}\text { Conceptual } \\
\text { analysis of content }\end{array}$ & $\begin{array}{l}\text { Methodological } \\
\text { analysis of content }\end{array}$ & $\begin{array}{l}\text { Evaluative analysis } \\
\text { of content }\end{array}$ \\
\hline
\end{tabular}

Source: Rico (2019) our translation.

This table shows some specificities that can be analyzed in curriculum studies and considered in planning actions for teacher training.

\section{Methodology}

This research is of the qualitative type and performs a study characterized as documentary type, which according to Ludke and Andre (2013) aims to study documents from primary sources with the intention of answering some research question. They also consider that this type of research is relevant when documentary analysis is necessary to understand the research topic.

We consider in this investigation the primary sources of the curricular documents analyzed, in the said case the Pedagogical Project of the Mathematics Course and the guiding document for the career of Pedagogy in Average Education, the curricular mesh of the course of the Chilean institution.

For its realization Ludke and Andre (2013) consider it important to carry out content analysis, which becomes a category of procedures to understand textual analysis and the social aspects that involve it. Thus the text is studied in view of its wider social context. In our analysis because these are specific curricular documents for the initial teacher education and training, the way curricula are presented and developed are intrinsically linked to what will be the performance actions of these teachers in their pedagogical practice.

The documents were read in full and we focused our analyzes, in the disciplines that compose the courses, in their specificities and training profiles. Thus we analyze the curricular differences, as well as their similarities, promoting reflection on the aspects mentioned by our authors of the theoretical reference Pires (2015) and Rico (2019). 


\section{The documents analyzed}

In this study we analyzed the Pedagogical Project of the Mathematics Course of the Federal University of Grande Dourados - Brazil, the guiding document for the career of Pedagogy in Chilean Middle Education and the curriculum of the pedagogy course in mathematics and computation, Universidade Católica do Maule. - Chile.

The Pedagogical Project of the Mathematics Course of the Federal University of Grande Dourados was updated in 2017 and brings the legislation and documents in force for the creation of the course, presents the history of the university and later the creation of the course. It evidences its justifications and needs for its implementation. Shows the characterization of the course, classes, periods of operation and possible number of students. Describes the conception and profile of the course and student egress, brings objectives and goals, its disciplines, ideal spreadsheet for courses, subjects for equivalence, workload, menu and bibliographic references.

The guiding document for the career of Pedagogy in Chilean Middle Education, published in 2012, has the pedagogical and curricular goals for all curricular components: a) language and communication, Mathematics, History, Geography and Social Sciences, Biology, Physics, Chemistry. The paper presents a presentation, the basic professional skills that guide the training of teachers and their teaching. It also presents pedagogical knowledge that the teacher must contain for teaching. As for the specificities of mathematical content we have: numerical systems and algebra, calculus, algebraic structures, geometry and data and chance.

The curricular grid of the pedagogy course in mathematics and computation of the Catholic University of Maule. - Chile, presents the subjects to be studied, the year and the semester.

\section{The context of the degree in Mathematics in universities}

The degree course in Mathematics at the Federal University of Grande Dourados (UFGD) was created in 2005. Soon after the dismemberment of the Dourados campus of the Federal University of Mato Grosso do Sul (UFMS) in the same year.

The dismemberment provided the university with greater autonomy allowing them to construct the documents: Institutional Development Project (PDI) and an Institutional Pedagogical Project (PPI). 
These documents are governed by CNE / CP Resolutions 01 and 02 of 2002 and the National Curricular Guidelines of Resolution CNE / CES no. 3 of 2003.

The Catholic University of Maule was created in 1991 and derives from the Pontifical Catholic University of Chile, with headquarters in San Miguel de Talca. Thus its history is divided into three periods: Normal School, Regional Headquarters, Institution of Autonomous Superior Education.

The modality of graduation with the objective of forming teachers of Mathematics at the Catholic University of Maule is called Pedagogy in Mathematics and Computing and was created and implemented in the year 2004. Its purpose is to integrate the new information technologies in educational actions.

The training in this course is organized with: 1) pedagogical training that develops knowledge so that they become mediators in the teaching and learning process of their future students; 2) development of the acquaintance 2) development of specific disciplinary and didactic knowledge of mathematical content, as well as the use of new teaching technologies; 3) personal, ethical and values training that allows the integral formation of future teachers.

In light of the above sections, we will present the analysis of curricular documents.

\section{Curricular analysis of the Mathematics course: Brazil and Chile}

When we read the documents we identified an organization different from the courses offered to undergraduate students in Mathematics. As we can see in the following table.

Table 1 - Curriculum of the subjects of the Brazilian and Chilean courses

\begin{tabular}{|c|c|c|c|}
\hline Year & Semester & Brazil & Chile \\
\hline \multirow[t]{6}{*}{1} & \multirow[t]{6}{*}{1} & $\begin{array}{l}\text { Components of the thematic } \\
\text { axis of the University I }\end{array}$ & Álgebra \\
\hline & & $\begin{array}{l}\text { Components of the thematic } \\
\text { axis of the University II }\end{array}$ & Geometry I \\
\hline & & Policy and Management & $\begin{array}{l}\text { Introduction to Mathematics } \\
\text { Teaching }\end{array}$ \\
\hline & & $\begin{array}{l}\text { Fundamentals of Mathematics } \\
\text { I }\end{array}$ & $\begin{array}{l}\text { Fundamentals } \\
\text { Computation }\end{array}$ \\
\hline & & $\begin{array}{l}\text { Fundamentals of Mathematics } \\
\text { II }\end{array}$ & $\begin{array}{l}\text { Historical fundamentals of } \\
\text { pedagogical thinking }\end{array}$ \\
\hline & & & Philosophical and \\
\hline
\end{tabular}




\begin{tabular}{|c|c|c|c|}
\hline & & & $\begin{array}{l}\text { epistemological foundations } \\
\text { of education }\end{array}$ \\
\hline & \multirow[t]{7}{*}{2} & Introduction to Calculus & Linear Algebra \\
\hline & & Special Education & Geometry II \\
\hline & & Fundamentals of Didactics & Introduction to Calculus \\
\hline & & $\begin{array}{l}\text { Fundamentals of Mathematics } \\
\text { III }\end{array}$ & Programming \\
\hline & & Elementary algebra & $\begin{array}{l}\text { Sociological foundations of } \\
\text { education }\end{array}$ \\
\hline & & Elective II & $\begin{array}{l}\text { Psychological foundations of } \\
\text { education }\end{array}$ \\
\hline & & & English I \\
\hline \multirow[t]{13}{*}{2} & \multirow[t]{7}{*}{3} & $\begin{array}{l}\text { Linear algebra and analytical } \\
\text { geometry }\end{array}$ & Theory of numbers \\
\hline & & $\begin{array}{l}\text { Differential and integral } \\
\text { calculus I }\end{array}$ & Geometry III \\
\hline & & $\begin{array}{l}\text { Developmental and learning } \\
\text { psychology }\end{array}$ & $\begin{array}{l}\begin{array}{l}\text { Differential and integral } \\
\text { calculus }\end{array} \\
\end{array}$ \\
\hline & & Geometric Constructions & Structure and algorithm \\
\hline & & $\begin{array}{l}\text { Mathematics Teaching Practice } \\
\text { I }\end{array}$ & $\begin{array}{l}\text { Human development and } \\
\text { educational inclusion }\end{array}$ \\
\hline & & Electiva III & Induction practice \\
\hline & & & English II \\
\hline & \multirow[t]{6}{*}{4} & Probability and statistics & Algebraic structures I \\
\hline & & $\begin{array}{ll}\text { LIBRAS - Brazilian signal } \\
\text { language }\end{array}$ & Data analysis \\
\hline & & Linear Algebra & $\begin{array}{l}\begin{array}{l}\text { Calculation } \\
\text { variables }\end{array} \\
\text { in }\end{array}$ \\
\hline & & Cálculus II & Didatics of geometry \\
\hline & & $\begin{array}{l}\text { Mathematics teaching practice } \\
\text { II }\end{array}$ & $\begin{array}{l}\text { Workshop on computational } \\
\text { strategies }\end{array}$ \\
\hline & & Elective IV & $\begin{array}{lll}\begin{array}{l}\text { Curricular } \\
\text { planning }\end{array} & \text { design } & \text { and } \\
\end{array}$ \\
\hline \multirow[t]{10}{*}{3} & \multirow[t]{6}{*}{5} & Arithmetic & Algebraic Structures II \\
\hline & & 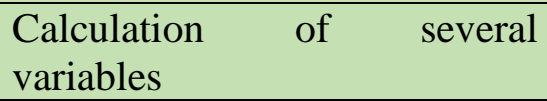 & Probabilistic models \\
\hline & & flat geometry & Didatica of Algebra \\
\hline & & $\begin{array}{l}\text { Mathematics teaching practice } \\
\text { III }\end{array}$ & Evolution of learning \\
\hline & & $\begin{array}{l}\begin{array}{l}\text { Internship supervised } \\
\text { elementary school I }\end{array} \\
\end{array}$ & $\begin{array}{l}\text { New technologies applied to } \\
\text { the generation of knowledge }\end{array}$ \\
\hline & & Elective V & Practicing intermediary \\
\hline & \multirow[t]{4}{*}{6} & $\begin{array}{l}\text { Design and research in } \\
\text { mathematical education and } \\
\text { education }\end{array}$ & Numerical calculation \\
\hline & & $\begin{array}{lrl}\text { Vector calculus } & \text { and } \\
\text { differential equations } & \end{array}$ & Real analysis \\
\hline & & Spatial Geometry & Didatica of the statistic \\
\hline & & $\begin{array}{l}\text { History of mathematics for the } \\
\text { teaching of mathematics }\end{array}$ & $\begin{array}{l}\text { Educational and vocational } \\
\text { guidance }\end{array}$ \\
\hline
\end{tabular}




\begin{tabular}{|c|c|c|c|}
\hline & & $\begin{array}{l}\text { Mathematics Teaching Practice } \\
\text { IV }\end{array}$ & School management \\
\hline & & $\begin{array}{l}\text { Internship Supervised in } \\
\text { elementary education II }\end{array}$ & Certification I \\
\hline 4 & 7 & $\begin{array}{l}\text { Algebraic structures } \\
\text { Certification II } \\
\text { Estruturas algébricas }\end{array}$ & $\begin{array}{l}\text { History and epistemology of } \\
\text { mathematics }\end{array}$ \\
\hline & & Mathematical analysis I & Differential equations \\
\hline & & $\begin{array}{lrr}\text { Computer Science } & \text { in } \\
\text { Mathematics Education } & \\
\end{array}$ & Didatica of Calculus \\
\hline & & $\begin{array}{l}\text { Mathematics Teaching Practice } \\
\mathrm{V}\end{array}$ & $\begin{array}{ll}\text { Quantitative } & \text { Research } \\
\text { Methodology } & \\
\end{array}$ \\
\hline & & $\begin{array}{l}\text { Supervised Internship in High } \\
\text { School I }\end{array}$ & $\begin{array}{ll}\text { Qualitative } & \text { Research } \\
\text { Methodology } & \\
\end{array}$ \\
\hline & & Course Completion Work & Introduction to Faith \\
\hline & & & Certification II \\
\hline & 8 & Mathematical Analysis II & $\begin{array}{l}\text { Integration of mathematical } \\
\text { contexts and knowledge }\end{array}$ \\
\hline & & Discrete Mathematics & $\begin{array}{l}\text { Workshop for Mathematics } \\
\text { Teaching }\end{array}$ \\
\hline & & Physics I & $\begin{array}{l}\text { Synthesis of the Degree in } \\
\text { Education }\end{array}$ \\
\hline & & Human Rights Education & Ethics Crest \\
\hline & & $\begin{array}{l}\text { Science and culture in } \\
\text { mathematics education }\end{array}$ & Certification III \\
\hline & & $\begin{array}{l}\text { Supervised Internship in } \\
\text { Secondary Education II }\end{array}$ & \\
\hline & & Additional activities & \\
\hline 5 & 9 & & Professional Practice \\
\hline
\end{tabular}

Source: Adapted from UFGD (2017) and UCM (2019)

We note that the mathematical contents taught in both courses (Brazilian and Chilean) have similarities, however, we can observe much more disciplines of historical, philosophical, sociological and psychological knowledge than in Brazilian education. However we have some disciplines offered for methodological support, such as: the fundamentals of didactics and mathematics specifics, as well as a special education discipline that does not appear in the Chilean curricular component. It is also seen in the Brazilian formation of these teachers some disciplines that are offered for the social formation of this individual as quoted by Rico (2019) as one of its dimensions.

The Chilean undergraduate degree has a higher workload and therefore has one semester more than the course. Apart from practice and stage of the course is at the end of the course and still has partial certifications.

Another characteristic is the profile of the educator who wants to train, the Brazilian teacher is trained to work in the school institutions for teaching mathematics 
in a more technical and procedural way. This is especially noticeable when analyzing the syllabuses of the disciplines as well as their theoretical references.

The Chilean training also forms teachers to work in educational institutions, but the guiding document for the career of Pedagogy in Chilean Middle Education indicates the concern that there is with the pedagogical training and understanding of the mathematical contents for its teaching. Another interesting evidence is the provision of a foreign language in the curriculum of these teachers' training, given that the Chilean government has taught different languages since the beginning of schooling and so teachers should have their mastery.

With this we do not see in any of the two formative curricula the proposal of Pires (2015) in the study of the curriculum in the initial formations. We see strong evidence of the cognitive, conceptual, ethical, and formative dimension of Rico (2019) in both curricula.

In view of this analysis we consider that it is necessary to reflect on what teacher we are forming and that the problems occur in different countries.

\section{Considerations}

We compare the pedagogical projects of the Mathematics course in two Brazilian institutions (Federal University of Grande Dourados) and one Chilean (Universidade Católica do Maule). In analyzing the documents we did an analysis of the courses offered in both courses, our observations were based on the curriculum dimensions indicated by Rico (2019).

We have identified a set of disciplines in common in both courses regarding the conceptual and mathematical knowledge of formation, but there are significant differences as regards pedagogical, philosophical and sociological disciplines. These evidences show the differentiated profile that these formations will promote, in general the teachers will have knowledge about the area of mathematics, but the way in which they will promote the education can be differentiated, since the Chilean education develops a more political and methodological professional profile and the a more technical professional profile.

We also note that there is no specific discipline for curriculum study, which author Pires (2015) considers essential for the training of teachers. 
Thus, we note the importance of studies and reflections on the formative curricula of the degrees. In addition, changes in the initial training of teachers who teach mathematics are needed.

\section{REFERENCES}

CHILE. Ministerio de Educación. Estándares orientadores para carreras de pedagogía en educación media. Estándares pedagógicos y disciplinarios. Santiago: LOM Ediciones Ltda, 2012.

LUDKE, M.; ANDRE, M. E. D. A. Pesquisa em educação abordagens qualitativas. São Paulo: EPU, 1986.

PALANCH, W. B. de L. Currículos de Matemática: uma contribuição para o mapeamento de produções e identificação de novas demandas de pesquisa. 2015. (Doutorado em Educação Matemática). Programa de Estudos Pós-Graduados em Educação Matemática. Pontifícia Universidade Católica de São Paulo. São Paulo.

PIRES, C. M. C. Panorama da organização e desenvolvimento curricular de matemática no Brasil. Anais do III Fórum Nacional sobre Currículos de Matemática, 2015.

RICO, L. Categorías para el análisis de los contenidos didácticos en el currículo de matemáticas. Anais do XV Conferência interamericana de Educação Matemática. 2019

UCM, Universidade Católica do Maule. Grade curricular do curso pedagogia da Matemática e computação. 2019

UFGD, Universidade Federal da Grande Dourados. Projeto Pedagógico do Curso de Matemática. 2017

\section{Como referenciar este artigo}

LEVICOY, Danilo Diaz; ALENCAR, Edvonete Souza de. Curricular analysis of two undergraduate courses in Mathematics: Brazil and Chile. Revista on line de Política e Gestão Educacional, Araraquara, v. 23, n. esp. 1, p. 716-727, out. 2019. E-ISSN:15199029. DOI: https://doi.org/10.22633/rpge.v23iesp.1.13010

\section{Submetido em: 10/05/2019}

Revisões requeridas: 14/06/2019

Aprovado em: 10/08/2019

Publicado em: 01/10/2019 